\title{
Waste Paper Ash as Additives for High Strength Concrete Mix 45 MPa
}

\author{
Subanndi*, Fitriyati Agustina, Vebrian, Rafidah Azzahra \\ Universitas Muhammadiyah Kalimantan Timur, Jl.Ir.Juanda No.51, Samarinda, Kalimantan Timur 75124, Indonesia
}

Corresponding Author Email: 17111024430022@umkt.ac.id

https://doi.org/10.18280/acsm.440203

Received: 22 November 2019

Accepted: 12 February 2020

\section{Keywords:}

admixture, additive, rice husk ash, chemical, chemical content of cement

\begin{abstract}
High strength concrete is very widely used today to support the construction of buildings, roads, dams, bridges and so on. To make high quality concrete, additional material is needed as a concrete mixture, the added material today is very much in the market as well as added ingredients derived from fly ash, and rice husk, especially rice husk is most widely used as a mixture in making concrete, due to the chemical content of $\mathrm{SiO}_{2}$ contained in rice husk ash. In this study we made high strength concrete using ash derived from waste paper. Paper ash was burned manually and then filtered using sieve number 150. Paper ash was then tested for its chemical content. The results of the chemical content test derived from paper waste ash have a $\mathrm{CaO}$ of 92.70 while $\mathrm{SiO}_{2}$ is only $2.63 \%$. The making of test specimens was made as many as 90 pieces with some additional variations of noble ash from $0 \%, 5 \%, 10 \%, 15 \%, 20 \%$, and $25 \%$. Concrete compressive strength test results with a code of $0 \%$ could not achieve the quality plan of $45 \mathrm{MPa}$, while the addition of ash by $5 \%$ reached $41 \mathrm{MPa}$ compressive strength more, the highest compressive strength produced by a mixture of $10 \%$ paper ash which achieved a compressive strength of more than $45 \mathrm{MPa}$ plan. Whereas specimens with a mixture of $15 \%, 20 \%$, and $25 \%$ produce concrete with compressive strength below $36 \mathrm{MPa}$. From the results of the study it can be concluded that the use of 5\% and 10\% waste paper ash can increase the compressive strength of concrete. Ash from paper waste can be an alternative material added to the concrete mixture.
\end{abstract}

\section{INTRODUCTION}

Although high strength concrete is often considered a relatively new material, its development has been carried out in stages over many years. As development continues, the definition of high strength concrete has changed. In the 1950s, concrete with a compressive strength of $5000 \mathrm{psi}$ (34 MPa) was considered high strength. In the $1960 \mathrm{~s}$, concrete with 6,000 and $7500 \mathrm{psi}(41$ and $52 \mathrm{MPa}$ ) compressive strength was used commercially. In the early $1970 \mathrm{~s}, 9000 \mathrm{psi}(62 \mathrm{MPa})$ concrete was being produced. Recently, compressive strength approaching 20,000 psi (138 MPa) has been used in building castings in place [1].

Concrete is the most widely used material in the infrastructure of making roads, bridges, and buildings. So that manufacturers of building materials, especially competing to make added materials or concrete substitutes with various uses using chemicals, of course, this causes high prices for concrete. There are three concrete groupings according to SNI (Indonesian National Standard) [2] procedures for planning high strength concrete with Portland cement and fly ash based on compressive strength, low strength concrete (slow strength concrete) concrete with compressive strength below $20 \mathrm{MPa}$, quality concrete medium (medium strength concrete) with compressive strength of $20 \mathrm{Mpa}-40 \mathrm{Mpa}$, and high strength concrete(high strength concrete) with compressive strength above $40 \mathrm{Mpa}$. Whereas according to SNI 6468 high strength concrete is defined as concrete having compressive strength above $41.4 \mathrm{MPa}$ [3]. To make high strength concrete, it needs added material as a concrete mixture [4].
Various methods are carried out research to strengthen the quality of concrete such as Strength and Some Durability Properties of Concrete Containing Rice Husk Ash Produced in a Charcoal Incinerator at Low Specific Surface [5] Waste steel wires modified structural lightweight concrete [6]. Some use the nature of concrete fiber reinforced concrete material made with recycled earthquake waste [7].

The use of waste as a material making constituents of concrete materials has been done a lot to aim at reducing and utilizing waste into useful materials [8-11]. Rice husk ash has been widely researched as an added material or as a substitute material for a part of the cement matrix, the experiment of using rice husk ash is used as a concrete for high strength concrete, concrete with additional rice husk ash is able to provide additional strength of rice husk which has a chemical content of $\mathrm{SiO}_{2}$ which high, Calculation of the formation of mineral or phase types of rice husk ash showed that the rice husk ash did not have alite $(\mathrm{C} 3 \mathrm{~S})$ and balite $(\mathrm{C} 2 \mathrm{~S})$ compound whereas aluminate $(\mathrm{C} 3 \mathrm{~A})$ and ferrite $(\mathrm{C} 4 \mathrm{AF})$ were very low, each of which amounted to $0.44 \%$ and $0.98 \%$. Because rice husk ash does not have a $\mathrm{C} 3 \mathrm{~S}$ and $\mathrm{C} 2 \mathrm{~S}$ compound phase, rice husk ash cannot be classified as a matrix in the sense of cement [12]. However, because rice husk ash has a high content of $\mathrm{SiO}_{2}$, rice husk ash can be used as a partial replacement for the cement matrix of the chemical content of rice husk ash according to the paper [13] the chemical content of rice husk ash has a chemical content of $\mathrm{SiO}_{2}$ between $76 \%-86 \%$.

This research includes testing the waste material from paper ash in the form of chemical content, density and specific gravity, and the manufacture of high strength concrete 
specimens with a compressive strength of $45 \mathrm{MPa}$. The making of concrete specimens using paper ash material was carried out with some degree of adjusting the research conducted to make concrete with high quality $45 \mathrm{MPa}$ so that the results of the test specimens in this research can be concluded whether the paper ash added material can get high strength concrete according to the plan and whether the concrete is higher than the quality of the planned concrete or not, this study is to examine things that have not been done by previous researchers where the previous research that was referred to in this study did not test the chemical content and paper ash mixture Such experiments have not been carried out in the manufacture of normal concrete.

Paper Waste Ash As A High strength concrete mixture Additive $45 \mathrm{Mpa}$ (Alasbata Bom T45) is a waste paper ash as a high strength concrete mixture added $45 \mathrm{MPa}$, Alasbata BOM T45 is a study with the idea to utilize paper waste and reduce the cost of making concrete from getting higher. Therefore, a lot of research has been done to reduce the cost of concrete from waste, one of which is coal fly ash, coal fly ash has been considered successful in influencing the strength of concrete, but with difficulty and requires high operational costs to obtain coal fly ash ash, causing the use of coal fly ash cannot be applied until now. The output from our research will have an impact on reducing the high cost of concrete production and in terms of paper waste utilization. The chemical content of paper ash is very necessary for this study by knowing the chemical content of paper ash can be concluded classified as what paper ash is in the manufacture of normal concrete with high quality. Previous research made various levels of paper ash as an added material, the strength of concrete with a mixture of paper ash obtained an additional compressive strength of concrete at $25 \%$ paper ash content at the age of 28 days compressive strength increased from 240.74 $\mathrm{kg} / \mathrm{cm}^{2}$ (without paper ash) to $391,85 \mathrm{~kg} / \mathrm{cm}^{2}$ (with additional paper ash) there is an increase of approximately $80 \%$ strength of concrete with the use of paper ash, with an $80 \%$ increase in compressive strength of concrete in the SCC (SelfCompacting Concrete). The use of inexpensive super hydrophobic powder as a waterproof mixture or waterproof surface coating for concrete has been investigated. The powder is produced from sludge ash (PSA) paper, a by-product of recycled paper making. The effects of hydrophobic PSA on work properties, strength and transport properties, including sorptivity, water absorption, diffusivity, permeability, and electrical conductivity are reported. Samples using a water/cement ratio of 0.38 , were used up to 28 days and conditioned at $50^{\circ} \mathrm{C}$ for a constant mass before testing. That replacing Portland cement with a $12 \%$ hydrophobic PSA reduces water absorption, absorption and conductivity by $84 \%$, $86 \%$ and $85 \%$, respectively, without major adverse effects on hydration, strength and density. When used as a surface coating, hydrophobic PSA is reduced by both absorption and absorption by $85-99 \%$ depending on the adhesive used. The surface of the sample coated with hydrophobic PSA shows excellent water repellent characteristics and self cleaning [14].

\section{MATERIAL AND METHOD}

The main variables tested in this study consisted of independent variables and dependent variables. Independent variable.

\subsection{Paper ash making}

The paper used is paper, books, and paper used in various offices. The paper is put into a drum and burned at a temperature of $\pm 700^{\circ} \mathrm{C}$ after all the paper is perfectly turned into ash, let it cool down, then the ash is sieved using a sieve No.150 after it is tested on the ash of the paper. The results of making paper ash see Figure 1.

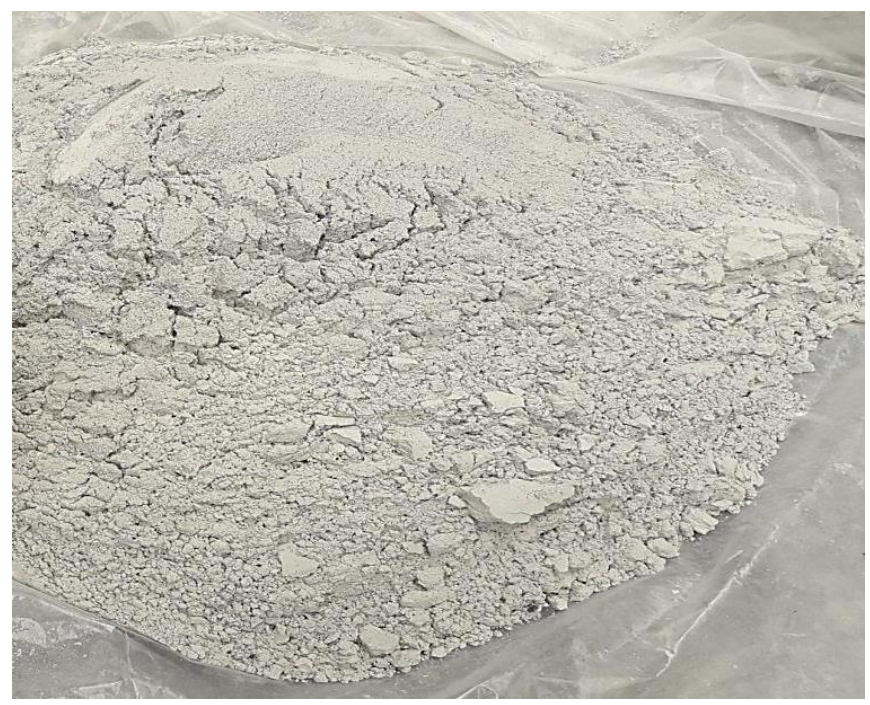

Figure 1. Paper ash that has been completed

Material testing is carried out based on the steps in accordance with SNI and ASTM, [15-23], the test result data as for the tests conducted, chemical content, specific gravity, heavy content of solid/loose paper ash, loose weight density and coarse aggregate solid, and, fine aggregate, specific gravity and absorption of coarse aggregate, and, fine aggregate. And coarse and fine aggregate mud content.

\subsection{Making concrete test objects}

The test specimens were made as many as 90 specimens, concrete materials for making specimens using ex palu crushed stone, ex palu sand, PCC cement, clean water, and paper ash, concrete designs using SNI 03-6468-2000 [3]. Making cylindrical specimens with a diameter of $15 \mathrm{~cm} \times 30$ cm 03-4810-1998 [24] $30 \mathrm{~mm}$ slump plan, with various variations in the percentage of mixed specimens with $0 \%$ ash content are comparative test specimens, the composition of mixtures and plans for the number of specimens can see Table 1.

Table 1. Number and age of testing objects

\begin{tabular}{ccccccc}
\hline Age of & \multicolumn{6}{c}{ Paper Ash Percentage } \\
\cline { 2 - 7 } Testing & $\mathbf{0 \%}$ & $\mathbf{5 \%}$ & $\mathbf{1 0} \%$ & $\mathbf{1 5} \%$ & $\mathbf{2 0} \%$ & $\mathbf{2 5} \%$ \\
\hline $\mathbf{3}$ & 3 & 3 & 3 & 3 & 3 & 3 \\
$\mathbf{7}$ & 3 & 3 & 3 & 3 & 3 & 3 \\
$\mathbf{1 4}$ & 3 & 3 & 3 & 3 & 3 & 3 \\
$\mathbf{2 1}$ & 3 & 3 & 3 & 3 & 3 & 3 \\
$\mathbf{2 8}$ & 3 & 3 & 3 & 3 & 3 & 3 \\
\hline
\end{tabular}

Manufacture and maintenance of test specimens see Figure 2(a) and 2(b) 


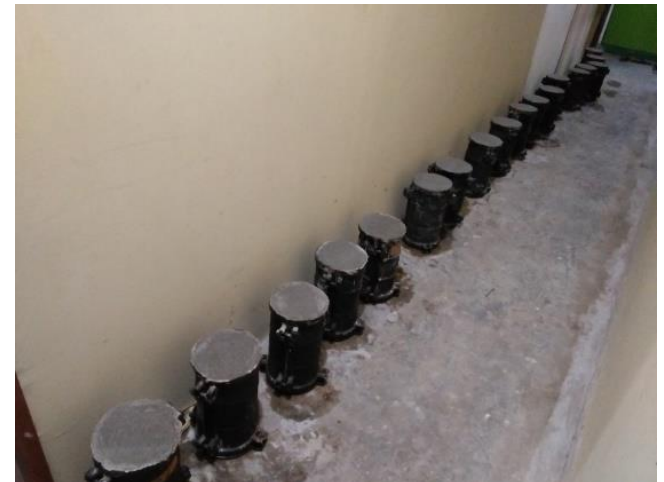

(a). Manufacture of test specimens

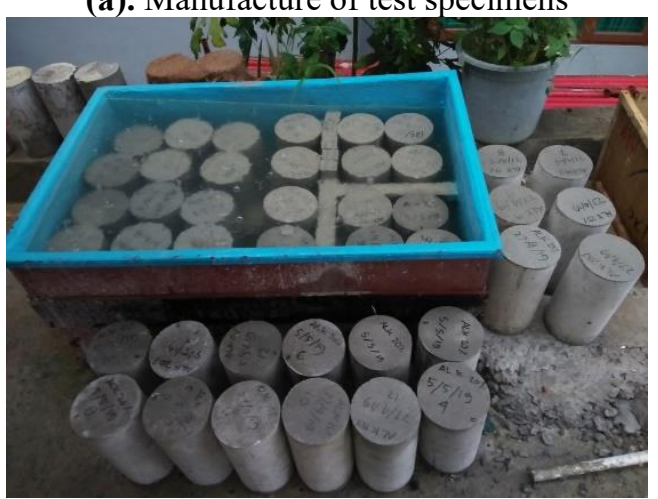

(b). Care of test specimens

Figure 2. Making test objects and maintaining test specimens

\subsection{Slump test}

Wet the mold and place it on a flat, damp, non-absorbent and stiff surface. The mold must be held firmly in place during filling, by the operator standing on the stampede. From the concrete samples obtained, immediately fill the mold in three layers, each layer approximately one third of the volume of the mold.

Solid each layer with 25 stitches using a compacting rod. Spread the stitching evenly over the surface of each layer. For the lower layer this will require a skewed incision and make approximately half of the number of punctures close to the edge of the mold, and then continue the vertical stabbing in a spiral around the center of the surface. Compact the entire layer down to its depth. Avoid puncturing sticks about the mold base plate. Compact the second layer and the top layer all the way to its depth, so that the puncture penetrates the boundary layer below.

In filling and compacting the top layer, add the concrete mixture over the mold before compaction begins. If solidification results in concrete falling below the top end of the mold, add a concrete stir to keep the excess concrete at the top of the mold. After the top layer is compacted, flatten the concrete surface at the top of the mold by rolling the piercing rod over it. Remove the mold from the concrete immediately by carefully lifting it in the vertical direction. Lift the mold $300 \mathrm{~mm}$ apart in $5 \pm 2$ seconds without lateral or torsional movements. Complete all test work from the start of filling to removing the mold without interruption, in no more than $2 \frac{1}{2}$ minutes.

After the concrete shows a decrease in surface, measure the slump immediately by determining the vertical difference between the top of the mold and the center of the top surface of the concrete. In the event of collapse or collapse of concrete shear on one side or a portion of the concrete mass, ignore the test and make a new test with another portion of the sample [25].

\subsection{Compressive strength testing}

The test specimen is finished after 24 hours the specimen is removed from the cylindrical mold, the specimen is weighed, and put into a curing container every day the specimen is removed for weighing to determine the progress of the specimen from day to day each observation is recorded. Two days before concrete testing must be removed from the curing tub and placed in a shady and safe place [24].

Test specimens testing were carried out at three stages of ages; 7 days, 14 days, and 28 days by using compressive strength testing machines, before testing the test specimens, they were weighed and got capping by using sulfur on the upper surface. The testing was carried out by following the procedures and calculation method of ASTM [21].

Calculation of the test results was done by applying Eqns. (1) and (2):

$$
f_{\mathrm{cm}}=\frac{4000 P_{\max }}{\pi D^{2}}
$$

Inch-pund unit:

$$
f_{\mathrm{cm}}=\frac{4 P_{\max }}{\pi D^{2}}
$$

where,

$f_{\mathrm{cm}}=$ compressive strength, $\mathrm{MPa}(\mathrm{psi})$,

$\mathrm{Pmax}=$ maximum load, $\mathrm{kN}(\mathrm{lbf})$, and

$\mathrm{D}=$ Average measured diameter, $\mathrm{mm}$ (in)

\section{RESULTS AND DISCUSSION}

\subsection{Ash paper chemical content test results}

Paper ash test results obtained results see Table 2.

Table 2. Test results of the chemical content of paper ash

\begin{tabular}{lcc}
\hline \multicolumn{2}{c}{ SAMPLE CODE } & ABU LIMBAH KERTAS(ALK) \\
\hline \multicolumn{2}{c}{ PARAMETER } & RESULT \\
\hline $\mathrm{S}_{\mathrm{i}} \mathrm{O}_{2}$ & $\% \mathrm{db}$ & 2.63 \\
$\mathrm{Al}_{2} \mathrm{O}_{3}$ & $\% \mathrm{db}$ & 0.60 \\
$\mathrm{Fe}_{2} \mathrm{O}_{3}$ & $\% \mathrm{db}$ & 0.71 \\
$\mathrm{CaO}$ & $\% \mathrm{db}$ & 92.70 \\
$\mathrm{MgO}$ & $\% \mathrm{db}$ & 1.19 \\
$\mathrm{Na} 2$ & $\% \mathrm{db}$ & 0.42 \\
$\mathrm{~K}_{2} \mathrm{O}$ & $\% \mathrm{db}$ & 0.07 \\
$\mathrm{MnO}_{2}$ & $\% \mathrm{db}$ & 0.03 \\
$\mathrm{TiO}_{2}$ & $\% \mathrm{db}$ & 0.40 \\
$\mathrm{P}_{2} \mathrm{O}_{5}$ & $\% \mathrm{db}$ & 0.30 \\
$\mathrm{SO}_{3}$ & $\% \mathrm{db}$ & 0.22 \\
\hline $\mathrm{Undetermined}_{3}$ & $\% \mathrm{db}$ & 0.73 \\
\hline
\end{tabular}

Note: Test results of the chemical content of the waste paper

From the results of testing paper ash as shown in Table 2 the dominant chemical content in paper ash is $\mathrm{CaO}$ while $\mathrm{SiO}_{2}$ is very small, this is the opposite of rice husk ash, as is known the chemical content found in ordinary cement is $\mathrm{CaO}$ [26]. Chemical content contained in cement can be seen in Table 3. 
Table 3. Chemical content of cement

\begin{tabular}{cc}
\hline Chemical Compound & \% \\
\hline $\mathrm{CaO}$ & 64.40 \\
$\mathrm{SiO}_{2}$ & 2.60 \\
$\mathrm{Al}_{2} \mathrm{O}_{3}$ & 4.30 \\
$\mathrm{Fe}_{2} \mathrm{O}_{3}$ & 2.40 \\
$\mathrm{MgO}$ & 2.10 \\
$\mathrm{SO}_{3}$ & 2.30 \\
$\mathrm{Na}_{2} \mathrm{O}+\mathrm{K}_{2} \mathrm{O}$ & 1.20 \\
\hline
\end{tabular}

Note: Chemical content of ordinary cement according to M. B. Varma and P. Gadling

When compared to the chemical content of paper ash and the chemistry of cement, the two materials have more similarities, both of which have the same high $\mathrm{CaO}$ chemistry, between cement and ash. Whereas rice husk ash has a very low $\mathrm{CaO}$ chemical content.

\subsection{Material testing results}

The results of testing of coarse aggregate, fine aggregate, paper waste ash, and rice husk ash include specific gravity, fill weight, absorption, gradation, etc. are presented in Table 4.

Table 4. Material testing results

\begin{tabular}{ccccc}
\hline NO & Material & $\begin{array}{c}\text { Coarse } \\
\text { Aggregate }\end{array}$ & Sand & $\begin{array}{c}\text { Husk Ash } \\
\text { Paper }\end{array}$ \\
\hline $\mathbf{1}$ & Solid fill weight & $1.485,90$ & 1631,29 & 443,5 \\
\hline $\mathbf{2}$ & Crumbly fill weight & $1.408,30$ & $1.476,61$ & 441,8 \\
\hline $\mathbf{3}$ & Specific gravity & 2,51 & 2,473 & 2,59 \\
\hline $\mathbf{4}$ & Water Absorption & 2,04 & 0.012 & 29,76 \\
\hline $\mathbf{5}$ & Fine-grain modulus & 7,67 & 3.16 & - \\
\hline $\mathbf{6}$ & Abrasion & 32,826 & - & - \\
\hline $\mathbf{7}$ & Organic matter & - & 1 & - \\
\hline $\mathbf{8}$ & Sludge content & 1,58 & 0,31 & - \\
\hline $\begin{array}{l}\text { Note: } \\
\text { specimens } \text { results of testing the }\end{array}$ & & &
\end{tabular}

\subsection{Mix design}

Mix design using SNI 03-6468-2000 with compressive strength of $45 \mathrm{MPa}$ plan, $30 \mathrm{~mm}$ slump. after the mix design results are generated then the addition of ash paper in accordance with the percentage of each experiment. Mix designs can be seen in Table 5 .

Table 5. The results of the mix design

\begin{tabular}{cccccc}
\hline $\begin{array}{c}\text { Code } \\
\text { ALK }\end{array}$ & $\begin{array}{c}\text { Water } \\
(\mathbf{k g})\end{array}$ & $\begin{array}{c}\text { Cement } \\
(\mathbf{k g})\end{array}$ & $\begin{array}{c}\text { Coarse } \\
\text { Aggregate } \\
(\mathbf{k g})\end{array}$ & $\begin{array}{c}\text { Fine } \\
\text { Aggreg } \\
\text { ate (kg) }\end{array}$ & $\begin{array}{c}\text { Paper } \\
\text { Ash } \\
(\mathbf{k g})\end{array}$ \\
\hline $0 \%$ & 190 & 527 & 944 & 683 & 0,00 \\
\hline $5 \%$ & 190 & 527 & 944 & 683 & 9,50 \\
\hline $10 \%$ & 190 & 527 & 944 & 683 & 19,00 \\
\hline $15 \%$ & 190 & 527 & 944 & 683 & 28,50 \\
\hline $20 \%$ & 190 & 527 & 944 & 683 & 38,00 \\
\hline $25 \%$ & 190 & 527 & 944 & 683 & 47,50 \\
\hline
\end{tabular}

Note: The percentage of the mixture is multiplied by the amount of cement used

\subsection{Slump test results}

Slump test results obtained $0 \%$ concrete results slump according to the plan $30 \mathrm{~mm}$ while the addition of paper ash by $5 \%$ results obtained $25 \mathrm{~mm}, 10 \% 21 \mathrm{~mm}, 15 \% 18 \mathrm{~mm}, 20 \%$ $11 \mathrm{~mm}$, and $25 \% 6 \mathrm{~mm}$. the greater the percentage of the addition of paper ash the smaller the slump produced.

\subsection{Compressive strength test}

From the compressive strength test results of the specimens, the concrete compressive strength test results can be seen in Table 6.

Table 6. Compressive strength test results

\begin{tabular}{ccccccc}
\hline \begin{tabular}{c} 
Age of $\begin{array}{c}\text { Test } \\
\text { Object } \\
\text { (days) }\end{array}$ \\
\cline { 2 - 7 }
\end{tabular} & \multicolumn{6}{c}{$\begin{array}{c}\text { Compressive Strength (MPa) based on } \\
\text { Percentage of Paper Ash }\end{array}$} \\
\hline 3 & 19.52 & $5 \%$ & $10 \%$ & $15 \%$ & $20 \%$ & $25 \%$ \\
\hline 7 & 30.44 & 21.22 & 33.25 & 25.15 & 31.27 & 25.45 \\
\hline 14 & 36.54 & 39.88 & 40.80 & 27.09 & 34.57 & 31.34 \\
\hline 21 & 37.73 & 40.85 & 41.64 & 32.62 & 33.34 & 33.17 \\
\hline 28 & 38.95 & 41.30 & 45.47 & 37.46 & 33.75 & 33.55 \\
\hline
\end{tabular}

From Table 6 it can be seen that the compressive strength of concrete using 10\% additional paper ash has better compressive strength than the compressive strength with various percentages of paper ash. Increasing the amount of paper ash in the mixture above $10 \%$ has decreased strength.

All variations in the mixture of paper ash additions have increased in the age of the test object. But the increase in strength is not significant when compared with a mixture of paper ash by $5 \%$, and $10 \%$. Test specimens with $10 \%$ content always dominate the strength of concrete from 3 days to 28 days.

\subsection{Discussion}

The results of the chemical ash testing of paper have higher $\mathrm{CaO}$ and $\mathrm{SiO}_{2}$ are very small, the chemical ash of paper ash is very different from rice husk ash and fly ash, where rice husk ash and fly ash have very large $\mathrm{SiO}_{2}$. while the chemical content contained in cement has a higher $\mathrm{CaO}$ chemical content. chemicals contained in paper ash have similarities with the chemical content held by ordinary cement.

The results of comparative test specimens $(0 \%)$ did not achieve the compressive strength of the plan of $45 \mathrm{MPa}$, this is in line with the almufid theory that to get high quality concrete must use additional additives, without the addition of concrete materials, concrete cannot produce high quality concrete. Test specimens with the addition of 5\% and $10 \%$ paper ash have a strength of $41.30 \mathrm{Mpa}$ and $45.47 \mathrm{MPa}$, so that both variations of the additional ash mixture can already be said to be made of high-quality concrete. The highest strength is obtained by a mixture of paper ash by $10 \%$ which produces compressive strength according to plan. while variations of the mixture above $10 \%$ cannot reach the strength of the plan, or still below the strength of the mixture with $5 \%$ and $10 \%$ content. the chemical content of $\mathrm{CaO}$ contained in paper ash, gives a reaction to the addition of a certain degree of concrete strength. The development of concrete compressive strength from ages 3, 7, 14, 21, and 28 days is shown in Figure 3. And the concrete compressive strength of various variations is shown in Figure 4. 


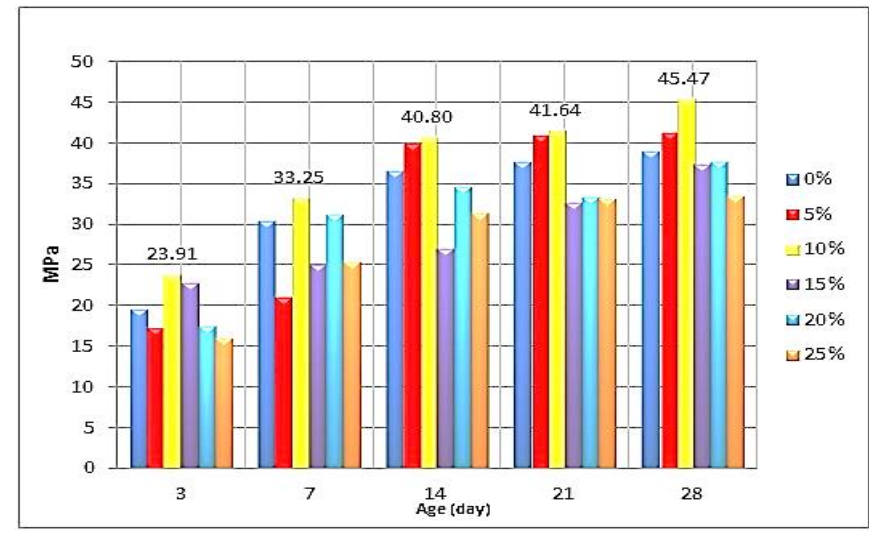

Figure 3. Development of concrete compressive strength of $3,7,14,21$, and 28 days

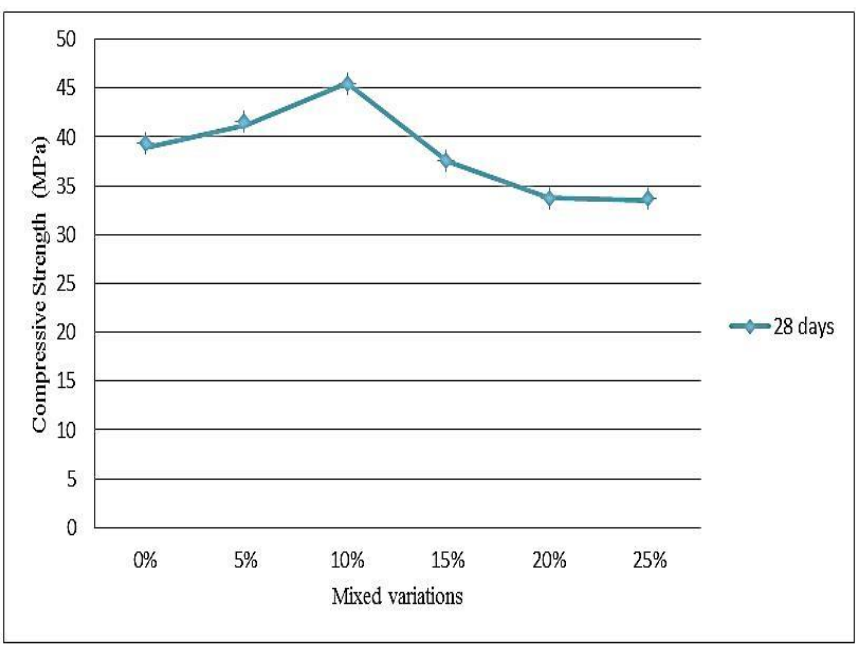

Figure 4. Compressive strength of each 28-day age variation

\section{CONCLUSIONS}

From the results and discussion it can be concluded the results of this study:

(1) The results of testing the chemical content of paper ash, paper ash has a very high $\mathrm{CaO}$ chemical content that is above $92.70 \%$ while $\mathrm{SiO}_{2}$ is only $2.63 \%$.

(2) The chemical content of paper ash is similar to the chemical found in ordinary cement.

(3) The greater the addition of paper ash, the smaller the slump obtained.

(4) To make concrete with high quality, a mixture of added materials is needed in making concrete.

(5) The addition of 5\% and 10\% paper ash can increase the strength of concrete, and the highest compressive strength of concrete is produced by concrete with an additional $10 \%$ of paper ash.

(6) The addition of paper ash as much as $10 \%$ of the weight of cement, producing a concrete compressive strength of $45.47 \mathrm{MPa}$. there is an increase in compressive strength of $6,52 \mathrm{MPa}$ when compared with the comparative test object $(0 \%)$, which only produces a compressive strength of 38,95 $\mathrm{MPa}$.

(7) Paper waste ash can be used as an alternative material for high-performance concrete mixes.

\section{ACKNOWLEDGMENT}

We would like to thank the Ministry of Research and Technology Education of the Republic of Indonesia for funding this research, thank you also to Professor Bambang Setiaji as the chancellor and Mr. H. Sunarso, S.E., M.M as the second vice-rector of Universitas Muhammadiyah Kalimantan Timur.

\section{REFERENCES}

[1] ACI Committee 363. (1984). State of the art report on high-strength concrete. International Concrete Abstracts Portal, 81(4): 364-411.

[2] Standar Nasional Indonesia. (2000). Standar nasional Indonesia Tata cara pembuatan rencana campuran beton normal. SNI 03-2834-2000.

[3] Standar Nasional Indonesia. (2000). Tata cara perencanaan campuran tinggi dengan semen portland dengan abu terbang. SNI 03-6468-2000.

[4] Almufid. (2015). Beton Mutu Tinggi dengan bahan Tambahan. Jurnal Fondasi, 4(2): 81-87.

[5] Abalaka, A.E. (2013). Strength and some durability properties of concrete containing rice husk ash produced in a charcoal incinerator at low specific surface. Int. J. Concr. Struct. Mater., 7: 287-293. https://doi.org/10.1007/s40069-013-0058-8

[6] Aghaee, A., Yazdi, M.A. (2014). Waste steel wires modified structural lightweight concrete. Mater. Res., 17(4): 958-966. https://doi.org/10.1590/15161439.257413

[7] Dong, J.F., Wang, Q.Y., Guan, Z.W. (2017). Material properties of basalt fibre reinforced concrete made with recycled earthquake waste. Constr. Build. Mater., 130: 241-251.

https://doi.org/10.1016/j.conbuildmat.2016.08.118

[8] Subandi, Kusuma, C., Asnan, M.N., Damaiyanti, M., Yatnikasari, S. (2019). Manufacture of concrete with artificial sand from rice husk waste. International Journal of Recent Technology and Engineering, 8(3): 1670-1673. https://doi.org/10.35940/ijrte.C4438.098319

[9] Subandi, Nasrulah, T., Arha, A.A., Zulkarnain, I., Asnan, M.N. (2019). Effect of addition of rice husk charcoal on concrete compressive strength. International Journal of Engineering and Advanced Technology, 8(6): 49514955. https://doi.org/10.35940/ijeat.F9251.08861

[10] Subandi, Cahyono, R.H., Kusuma, C., Asnan, M.N. (2019). Artificial aggregate lightweight structural. Annales de Chimie - Science des Matériaux, 43(4): 213216. https://doi.org/10.18280/acsm.430403

[11] Subandi, Arha, A.A., Kusuma, C., Asnan, M.N. (2019). Utilization of ironwood waste and husk charcoal to produce lightweight concrete. International Journal of Civil Engineering, 6(7): 17-22. https://doi.org/10.14445/23488352/IJCE-V6I7P104

[12] Van Lam, T., Bulgakov, B., Aleksandrova, O., Larsen, O., Ngoc Anh, P. (2018). Effect of rice husk ash and fly ash on the compressive strength of high performance concrete. E3S Web of Conferences, 33: 02030. https://doi.org/10.1051/e3sconf/20183302030

[13] Raheem, A.A., Kareem, M.A. (2017). Chemical composition and physical characteristics of rice husk ash blended cement. International Journal of Engineering 
Research in Africa, 32: 25-35. https://doi.org/10.4028/www.scientific.net/JERA.32.25

[14] Wong, H.S., Barakat, R., Alhilali, A., Saleh, M., Cheeseman, C.R. (2015). Hydrophobic concrete using waste paper sludge ash. Cement and Concrete Research, 70: 9-20. https://doi.org/10.1016/j.cemconres.2015.01.005

[15] Pusat Penelitian dan Pengembangan Transportasi Jalan, Metode Pengujian Jumlah Bahan Dalam Agregat. SNI 03-4142-1996, 200: 1-6. 1996.

[16] ASTM C136/C136M, ASTM C136/C136M - 14 Standard Test Method for Sieve Analysis of Fine and Coarse Aggregates. https://www.astm.org/Standards/C136, accessed on 30Jul-2019.

[17] ASTM D2013/D2013M - 12 Standard Practice for Preparing Coal Samples for Analysis. https://www.astm.org/DATABASE.CART/HISTORIC AL/D2013D2013M-12.htm, accessed on 16-Sep-2019.

[18] Sni-astm-c136-2012. (2012). Metode Uji Untuk Analisis Saringan Agregat Halus dan Agregat Kasar (ASTM C 136-06, IDT).

[19] ASTM D3682 - 13 Standard Test Method for Major and Minor Elements in Combustion Residues from Coal Utilization Processes. https://www.astm.org/Standards/D3682, accessed on 21Aug-2019.

[20] ASTM C136 / C136M, “ASTM C136 / C136M - 14
Standard Test Method for Sieve Analysis of Fine and Coarse Aggregates," 2014. https://www.astm.org/Standards/C136, accessed on 30Jul-2019.

[21] ASTM-C39/C39M-18, ASTM C39 / C39M - 18 Standard Test Method for Compressive Strength of Cylindrical Concrete Specimens. https://www.astm.org/Standards/C39, accessed on 30Jul-2019.

[22] ASTM C127 - 15, ASTM C127 - 15 Standard Test Method for Relative Density (Specific Gravity) and Absorption of Coarse Aggregate. https://www.astm.org/Standards/C127, accessed on 30Jul-2019.

[23] ASTM D3682 - 13 Standard Test Method for Major and Minor Elements in Combustion Residues from Coal Utilization Processes. https://www.astm.org/Standards/D3682 accessed on 16Sep-2019.

[24] SNI 03-4810-1998. (1998). Metode Pembuatan dan Perawatan Benda Uji di Lapangan.

[25] SNI-1972-2008. (2018). Cara uji slump beton. Badan Standar Nasional Indonesia.

[26] Varma, M.B., Gadling, P. (2016). Additive to cement A pozzolanic material-fly ash. International Journal of Engineering Research, 3(5): 2319-68902347. https://doi.org/10.17950/ijer/v5i3/010 